\title{
Cervical Cancer cT2 TNM Finding v7
}

National Cancer Institute

\section{Source}

National Cancer Institute. Cervical Cancer CT2 TNM Finding v7. NCI Thesaurus. Code C89487.

Cervical cancer invades beyond uterus but not to pelvic wall or to lower third of vagina. (from AJCC 7th Ed.) 